\title{
Listeria monocytogenes, a down-to-earth pathogen
}

\author{
Anne-Laure Vivant ${ }^{1,2}$, Dominique Garmyn ${ }^{1,2}$ and Pascal Piveteau ${ }^{1,2 *}$ \\ 1 UMR1347 Agroécologie, Université de Bourgogne, Dijon, France \\ ${ }^{2}$ UMR1347 Agroécologie, INRA, Dijon, France
}

Edited by:

Alain Hartmann, Institut National de la Recherche Agronomique, France

Reviewed by:

Hélène Marquis, Cornell University, USA

Valerio lebba, 'Sapienza' University of Rome, Italy

${ }^{*}$ Correspondence:

Pascal Piveteau, UMR1347

Agroécologie, INRA, 17 rue Sully,

21000 Dijon, France

e-mail: piveteau@u-bourgogne.fr
Listeria monocytogenes is the causative agent of the food-borne life threatening disease listeriosis. This pathogenic bacterium received much attention in the endeavor of deciphering the cellular mechanisms that underlie the onset of infection and its ability to adapt to the food processing environment. Although information is available on the presence of $L$. monocytogenes in many environmental niches including soil, water, plants, foodstuff and animals, understanding the ecology of L. monocytogenes in outdoor environments has received less attention. Soil is an environmental niche of pivotal importance in the transmission of this bacterium to plants and animals. Soil composition, microbial communities and macrofauna are extrinsic edaphic factors that direct the fate of L. monocytogenes in the soil environment. Moreover, farming practices may further affect its incidence. The genome of $L$. monocytogenes presents an extensive repertoire of genes encoding transport proteins and regulators, a characteristic of the genome of ubiquitous bacteria. Postgenomic analyses bring new insights in the process of soil adaptation. In the present paper focussing on soil, we review these extrinsic and intrinsic factors that drive environmental adaptation of $L$. monocytogenes.

Keywords: Listeria, soil, contamination, occurrence, biodiversity, persistence, circulation, environment

\section{INTRODUCTION}

Circulation of zoonotic and Human pathogens within the biosphere is a major health issue. Agroecosystems may participate to the transmission of pathogens to the food chain through production of contaminated raw products. However, as illustrated in Figure 1, understanding conditions that will trigger such contaminations or, on the opposite that will limit risks of contamination is difficult in the face of the complexity of the ecology of microorganisms. Listeria monocytogenes is the agent of listeriosis, a food-borne illness. Health effects range from flu-like symptoms with vomiting and diarrhea in healthy adults to life-threatening diseases such as meningitis and septicaemia in vulnerable people and spontaneous abortion in pregnant women. In the light of these health hazards, this bacterium received much attention in order to understand the physiopathology of listeriosis. As a matter of fact, L. monocytogenes has become a paradigm for the study of intracellular pathogens. Similarly, the mechanisms that underlie its ability to persist in foodstuff and in the food manufacturing environment have been documented. However, the ecology of L. monocytogenes in outdoor environments is only partially understood. The objective of this review is to present the state of the art regarding extrinsic and intrinsic factors that shape the ecology of L. monocytogenes in the soil environment.

Understanding causal factors of agroecosystems invasion by human pathogens is required in a period of adaptation of farming practices to global changes in order to avoid emergence of health hazards related to increased circulation of pathogens.
DATA AVAILABLE ON THE OCCURRENCE OF L. monocytogenes IN SOIL

Several reports on the incidence of $L$. monocytogenes in soil are available (Table 1). The pioneering work by Welshimer presented the first evidence that soil is an environmental niche for L. monocytogenes and occurrence of the bacterium was observed in a third of the 12 sampled farms (Welshimer, 1960; Welshimer and Donker-Voet, 1971). This was further supported in the seventies by the work of Weis and Seeliger. These authors surveyed the occurrence of L. monocytogenes in 746 soil samples collected in Southern Germany. A total of 160 strains were isolated and the overall incidence of $L$. monocytogenes was $21.4 \%$ (Weis and Seeliger, 1975). In this study, variations from 8.4 to 44.0 in the percentage of positive samples were observed according to the type of culture in the field and the highest incidence was recorded for uncultivated fields and meadows. Higher prevalence in meadows and uncultivated fields (30.8\%) compared to cultivated fields $(8.3 \%)$ was confirmed later (Dowe et al., 1997). Similarly, in a recent survey of the distribution of the Listeria species in urban and natural environments in the US, while overall prevalence in soil was $19 \%$ in natural environments and $30 \%$ in urban environments, spatial variation of the prevalence of Listeria sp. was observed within each category (Sauders et al., 2012). Temporal variation of the detection of L. monocytogenes has been documented after sampling at the same site (Weis and Seeliger, 1975; Sauders et al., 2012). Moreover, prevalence differed significantly according to the season and category of environment. Indeed, it was highest during summer in natural environments but lowest at this time of the year in urban environments (Sauders et al., 2012).In another 


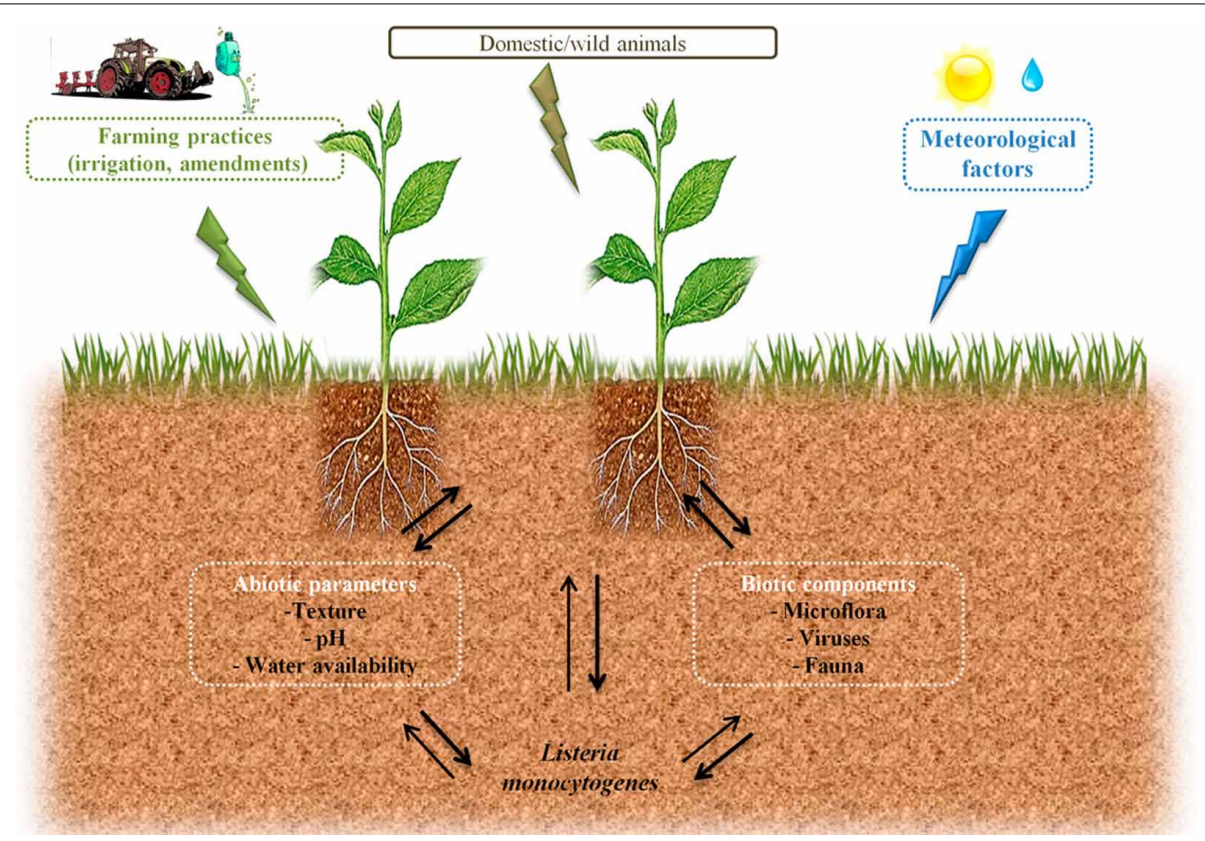

FIGURE 1 | Possible routes of transfer and circulation of $L$. monocytogenes in the farm environment and factors which can affect its survival in soil.

Table 1 | Listeria monocytogenes occurrence in soil and culture-based procedure used for its isolation.

\begin{tabular}{|c|c|c|c|c|}
\hline References & $\begin{array}{l}\text { Enrichment } \\
\text { procedure }\end{array}$ & Enrichment broth & $\begin{array}{l}\text { Condition of } \\
\text { incubation }\end{array}$ & $\begin{array}{l}\text { Percentage of soil detected } \\
\text { as positive }\end{array}$ \\
\hline Welshimer and Donker-Voet, 1971 & 2-step & $\mathrm{BH} I^{*}$ & $\begin{array}{l}4^{\circ} \mathrm{C}, 3.5-5 \text { months } \\
37^{\circ} \mathrm{C}, 24 \mathrm{~h}\end{array}$ & $\begin{array}{l}92 \% \text { of farm samples** } \\
86 \% \text { of the non-agricultural soil samples** }\end{array}$ \\
\hline Weis and Seeliger, 1975 & 1-step & $\begin{array}{l}\text { Lehnert + acriflavin } \\
(10 \mu \mathrm{g} / \mathrm{ml})\end{array}$ & $22^{\circ} \mathrm{C}, 7$ days & From $5.2-51.4 \%$ according to vegetation cover \\
\hline MacGowan et al., 1994 & 2-step & $\operatorname{LEB}^{* * *}$ & $\begin{array}{l}30^{\circ} \mathrm{C}, 48 \mathrm{~h} \text {, and } 7 \\
\text { days }\end{array}$ & $0.7 \%$ soils from urban origin \\
\hline Garcia et al., 1996 & 2-step & Two-step enrichment & & 8.3\% ewe's farmyard \\
\hline Dowe et al., 1997 & 2-step & LEB/Frazer broth & $\begin{array}{l}30^{\circ} \mathrm{C}, 48 \mathrm{~h} / 35^{\circ} \mathrm{C} \\
24-48 \mathrm{~h}\end{array}$ & $\begin{array}{l}8.3 \% \text { in carrot fields } \\
30.8 \% \text { in adjacent meadows }\end{array}$ \\
\hline Nightingale et al., 2004 & 1-step & LEB & $30^{\circ} \mathrm{C}, 48 \mathrm{~h}$ & $24 \%$ of samples from ruminant farms \\
\hline Fox et al., 2009 & 1-step & LEB & $30^{\circ} \mathrm{C}, 48 \mathrm{~h}$ & $3 \%$ of soils from dairy farms \\
\hline Sauders et al., 2012 & 1-step & LEB & $30^{\circ} \mathrm{C}, 24-48 \mathrm{~h}$ & $\begin{array}{l}7.1 \% \text { of soils collected from pristine field areas } \\
0.4 \% \text { of soils collected from pristine forest } \\
\text { areas } \\
10.7 \% \text { of soils collected from urban } \\
\text { environments }\end{array}$ \\
\hline Locatelli et al., 2013a & $\begin{array}{l}\text { 2-step } \\
\text { 2-step } \\
\text { 1-step }\end{array}$ & $\begin{array}{l}\text { LEB + modified LEB } \\
\text { Frazer broth } \\
\text { Frazer broth }\end{array}$ & $\begin{array}{l}37^{\circ} \mathrm{C}, 24-48 \mathrm{~h} \\
37^{\circ} \mathrm{C}, 48 \mathrm{~h} \\
4^{\circ} \mathrm{C}, 2 \text { months }\end{array}$ & $\begin{array}{l}17 \% \text { of field samples were positive in at least } \\
\text { one of the three enrichment procedure }\end{array}$ \\
\hline Strawn et al., 2013 & 1-step & $\begin{array}{l}\text { LEB supplemented } \\
\text { with a Listeria } \\
\text { selective enrichment } \\
\text { supplement }\end{array}$ & $30^{\circ} \mathrm{C}, 24-48 \mathrm{~h}$ & $\begin{array}{l}9 \% \text { of soils collected from fruit and vegetable } \\
\text { farms }\end{array}$ \\
\hline
\end{tabular}

*Brain heart infusion, ${ }^{* *}$ These figures should be considered cautiously as taxonomy of the genus Listeria has drastically evolved since the 70 ths, ${ }^{* * *}$ Listeria enrichment broth. 
report of a 3-year survey on fruit and vegetable farms, prevalence was higher in winter except during 1 year (Strawn et al., 2013) and correlation between season and occurrence is not a clear-cut. Incidence of L. monocytogenes in soil samples collected from small ruminant and cattle farms has also been recorded (Garcia et al., 1996; Nightingale et al., 2004; Fox et al., 2009).

In these surveys, detection always required selective enrichment. When available, the actual concentration of L. monocytogenes reported from soil samples is low (MacGowan et al., 1994; Dowe et al., 1997). It suggests that the population of L. monocytogenes in soil is generally low. This was confirmed in a French nationwide survey where a PCR assay was performed on a collection of 1232 soil DNA for the specific detection of L. monocytogenes (Locatelli et al., 2013a). All samples were below the detection limit of $10^{4} \mathrm{~g}^{-1}$ of dry soil. Interestingly, a comparison of cultivation-based and molecular detection on a subset of 53 fresh soil samples showed that the incidence of culturable L. monocytogenes was $17 \%$ but only one of these samples was positive for the molecular detection of L. monocytogenes and its population was quantified at $2.8810^{4} \mathrm{~g}^{-1}$ of dry soil (Locatelli et al., 2013a).

These surveys clearly demonstrate that soil is an environmental niche of L. monocytogenes but its population is generally low. Temporal and spatial variations of its occurrence point out that environmental factors drive the fate of L. monocytogenes in soil.

\section{EDAPHIC FACTORS THAT AFFECT ITS SURVIVAL}

Soil is an extremely complex and heterogeneous environment composed of minerals, organic matter, lacy plant roots and a complex biota including microorganisms, viruses, mesofauna and macrofauna. All of these are constantly interacting and soil may be regarded as an environment under dynamic equilibrium (Kogel-Knabner et al., 2008). Soil is characterized by complex food webs influenced by below-ground and above-ground processes (Wardle, 2006). As such, deciphering environmental drivers that impact the occurrence of L. monocytogenes in soil is extremely hard as these drivers are interconnected.

One of the conclusions that can be drawn from the results of the surveys presented above is that the nature of the soil affects the occurrence of L. monocytogenes. However, in these reports, indications of the soil characteristics are coarse. This makes it difficult to extract significant information regarding the relation between soil's characteristics and the presence of L. monocytogenes.

Investigations on listerial population dynamics after inoculation of soil microcosms (Table 2) evidenced that water availability is critical to its survival (Welshimer, 1960; Picardbonnaud et al., 1989; Vanrenterghem et al., 1991; Dowe et al., 1997). The type of soil affects population dynamics. Sandy soil represents an environment less favorable for L. monocytogenes than sandy loam and clay loam soils (Dowe et al., 1997); lower survival in clay soil than in fertile garden soil was also reported (Welshimer, 1960). A drawback of these studies is that only one soil of each type was used. A statistical approach to the analysis of $L$. monocytogenes survival in soils was recently performed to circumvent this limitation of the published data (Locatelli et al., 2013b). Data on the survival of L. monocytogenes in 100 soil microcosms was analyzed in the light of a comprehensive and detailed characterization of the soil samples (Locatelli et al., 2013b). These results confirmed that survival is dependent of the type of soil. Survival up to 84 days was

Table 2 | L. monocytogenes population dynamics after inoculation of soil microcosms.

\begin{tabular}{|c|c|c|c|c|}
\hline References & Soil type & $\begin{array}{l}\text { Condition of } \\
\text { incubation }\end{array}$ & $\begin{array}{l}\text { Inoculum } \\
\text { (CFU/g) }\end{array}$ & Population dynamics at the end of the experiment \\
\hline \multicolumn{5}{|l|}{ NON-STERILIZED SOILS } \\
\hline Welshimer, 1960 & $\begin{array}{l}\text { "Fertile" } \\
\text { "Clay" }\end{array}$ & $\begin{array}{l}30^{\circ} \mathrm{C}, 295 \\
\text { days }\end{array}$ & $1.10^{8}$ & $\begin{array}{l}\text { Decreased but still detectable throughout the incubation } \\
\text { Approached the zero level around Day } 195\end{array}$ \\
\hline Vanrenterghem et al., 1991 & Sandy loam & $\begin{array}{l}15^{\circ} \mathrm{C}, 8 \\
\text { weeks }\end{array}$ & $1.10^{5}$ & Intermittently detected during 6 weeks after incubation \\
\hline Dowe et al., 1997 & $\begin{array}{l}\text { Clay loam, sandy } \\
\text { loam and sandy }\end{array}$ & $\begin{array}{l}25-30^{\circ} \mathrm{C}, 32 \\
\text { days }\end{array}$ & $\begin{array}{l}1.10^{2} \\
1.10^{6}\end{array}$ & $\begin{array}{l}\text { Increase to } 10^{4} \text { in clay loam and sandy loam-stable in sandy soil } \\
\text { Decrease to } 10^{4} \text { in clay loam and sandy loam-less than } 10^{3} \text { in sandy soil }\end{array}$ \\
\hline Sidorenko et al., 2006 & $\begin{array}{l}\text { Brown podzolic } \\
\text { Forest } \\
\text { Urban }\end{array}$ & $\begin{array}{l}20-22^{\circ} \mathrm{C}, 7 \\
\text { days }\end{array}$ & $1.10^{2}$ & $\begin{array}{l}\text { Stable } \\
\text { Undetectable after Day } 2 \\
\text { Increase to } 10^{4}\end{array}$ \\
\hline McLaughlin et al., 2011 & Forest & $\begin{array}{l}8^{\circ} \mathrm{C}, 14 \text { days } \\
25 \text { and } 30^{\circ} \mathrm{C} \\
14 \text { days }\end{array}$ & $1.10^{6}$ & $\begin{array}{l}1.210^{3} \text { at the end of the experiment } \\
\text { Sharp decrease and undetected by Day } 8\end{array}$ \\
\hline Locatelli et al., 2013b & $\begin{array}{l}100 \text { contrasted } \\
\text { soils }\end{array}$ & $20^{\circ} \mathrm{C}, 84$ days & $1.10^{6}$ & Declined with time \\
\hline \multicolumn{5}{|l|}{ STERILIZED SOILS } \\
\hline Dowe et al., 1997 & $\begin{array}{l}\text { Clay loam, sandy } \\
\text { loam and sandy }\end{array}$ & $\begin{array}{l}25-30^{\circ} \mathrm{C}, 32 \\
\text { days }\end{array}$ & $\begin{array}{l}1.10^{2} \\
1.10^{6}\end{array}$ & $\begin{array}{l}\text { Increase to } 10^{5} \text { in clay loam-10 }-10^{4} \text { in sandy loam and sandy } \\
\text { Stable at } 10^{4} \text { in clay loam and sandy loam-down to } 10^{5} \text { in sandy soil }\end{array}$ \\
\hline McLaughlin et al., 2011 & Forest & $25^{\circ} \mathrm{C}, 14$ days & $1.10^{6}$ & Over 1 log increase within 2 days, then decrease down to $10^{6}$ \\
\hline Piveteau et al., 2011 & Loamy & $25^{\circ} \mathrm{C}, 1$ year & $1.10^{5}$ & Over 3 log increase in 2 days then slow decline to $10^{6} \mathrm{cfu}^{-1} \mathrm{~g}^{-1}$ \\
\hline Locatelli et al., 2013b & 9 contrasted soil & $20^{\circ} \mathrm{C}, 84$ days & $1.10^{6}$ & a rise ( 1 to $3 \mathrm{log}$ ) in 3 soils-Decline in 6 soils \\
\hline
\end{tabular}


observed in $71 \%$ of the soils tested while survival did not exceed 14 days in the rest of the soil microcosms. Variance partitioning explained this short-term survival by the soil chemical properties, especially the basic cation saturation ratio. The long-term survival could be related to the soil texture and especially clay content. The report by Locatelli et al. and others evidenced that the $\mathrm{pH}$ of the soil is a major driver of the fate of L. monocytogenes in soil (Weis and Seeliger, 1975; Sidorenko et al., 2006; McLaughlin et al., 2011; Locatelli et al., 2013b).

\section{ROLE OF SOIL MICROFLORA, MICROFAUNA, MESOFAUNA AND MACROFAUNA}

Soil is a rich and complex biotic environment that generates massive interest because of the immense diversity it harbors and the many services associated (Nannipieri et al., 2003; Decaens, 2010; Griffiths and Philippot, 2013). The impact of indigenous microorganisms on the fate of L. monocytogenes in soil has been addressed experimentally in microcosms. In these experiments, population dynamics of $L$. monocytogenes were compared in autoclaved and non-autoclaved soil microcosms. The results clearly demonstrated that autoclaving facilitates implantation of L. monocytogenes in soil as growth was observed in autoclaved soil while the population decreased in non-autoclaved soil (Welshimer, 1960; Botzler et al., 1974; Vanrenterghem et al., 1991; Dowe et al., 1997; McLaughlin et al., 2011). However, this effect of the soil microflora cannot be observed in soils with low $\mathrm{pH}$ as a decline of the listerial population was observed even in sterilized soils (Locatelli et al., 2013b). Interestingly, this antagonistic effect depends on the diversity and the structure of the soil microflora (Vivant et al., 2013). In this report, experimental erosion of diversity clearly showed that loss of biotic diversity resulted in a better survival of L. monocytogenes in soil.

In the complex food web of the soil environment, interactions of L. monocytogenes with microfauna, mesofauna and macrofauna are most likely and this assumption is supported by lab experiments.

Interaction of L. monocytogenes with bacteriophagous protozoans has been documented (Ly and Muller, 1990; Barker and Brown, 1994; Harf, 1994; Gourabathini et al., 2008). Once internalized by endocytosis, it can grow within the cytoplasm of Acanthamoeba sp. and Tetrahymena pyriformis and eventually causes lysis and death of the host within 8-14 days (Barker and Brown, 1994; Harf, 1994). In a study focused on Glaucoma sp. isolated from lettuce, Tetrahymena sp. isolated from spinach and Tetrahymena sp. isolated from soil, intracellular survival of L. monocytogenes was confirmed (Gourabathini et al., 2008). Finally, L. monocytogenes survives endocytosis by Acanthamoeba castellanii; this protozoan could actually enhance growth of the bacterium while feeding on various species of Listeria was not lethal to the protozoan (Zhou et al., 2007). These are indirect indications that protozoans can act as vectors of dispersion of L. monocytogenes in soil. However, other reports suggest that the ability of $L$. monocytogenes to survive after ingestion by protozoans may be strain and/or species specific as killing of L. monocytogenes by Acanthamoeba polyphaga, Acanthamoeba castellanii and Acanthamoeba lenticulata has been reported (Akya et al., 2009, 2010).
Reports on the role of free living nematodes feeding on bacteria as vectors of dispersion of food-borne pathogens are available in the literature (Anderson et al., 2003, 2006; Caldwell et al., 2003; Gibbs et al., 2005; Thomsen et al., 2006; Forrester et al., 2007; Zhou et al., 2007; Guha et al., 2013). Ceanorhabditis elegans can feed on L. monocytogenes, moreover, in an agar plate assay, presence of live cells in the gut and excrement was confirmed and shedding of the pathogen was evidenced (Anderson et al., 2003, 2006; Caldwell et al., 2003; Guha et al., 2013). Interestingly, shedding by Diploscapter sp., a bacteriovorous soil nematode, was observed in soil amended with composted turkey manure (Gibbs et al., 2005). Feeding on L. monocytogenes may have deleterious effects on C. elegans (Forrester et al., 2007) and killing of the nematode was demonstrated experimentally (Thomsen et al., 2006) but others did not report killing (Guha et al., 2013) and this remains an open question.

Information on interactions between L. monocytogenes and soil mesofauna and macrofauna is scarce (Kuzina et al., 2001; Mansfield et al., 2003; Sezen et al., 2004; Lapanje et al., 2010). However, these reports support the idea that several species of the soil meso- and macrofauna could act as reservoirs and vectors. Indeed, Listeria sp. was detected in the gut of the isopod Porcelio scaber (Lapanje et al., 2010) and in the gut of the Diptera Anastrepha ludens (Kuzina et al., 2001). Infection of another Diptera, Drosophila melanogaster, by L. monocytogenes has been demonstrated experimentally (Mansfield et al., 2003). In this work, intra-host multiplication was observed resulting in killing of the infected fruit flies within 6-8 days. Listeria sp. has been isolated from the bacterial flora of the Coleoptera Agelastica alni with a frequency of 18\% (Sezen et al., 2004). Finally, Listeria sp. was detected in half of 10 wormfarms sampled but L. monocytogenes was not isolated in any of them (Smith, 2001). Considering the diversity of the soil fauna (Decaens, 2010), one can assume that many species probably interact with L. monocytogenes. Elucidation of these complex interactions in the soil food web would bring a new understanding of the ecology of this food-borne pathogen. Moreover, wild animals including mammals and birds must be considered as potential zoonotic reservoirs of the pathogen (Weis and Seeliger, 1975; Yoshida et al., 2000; Lyautey et al., 2007b) and may participate to its transfer to soil.

\section{FARMING PRACTICES AND TRANSFER INTO THE SOIL (COMPOST, SEWAGE SLUDGES, RECLAIMED WASTE)}

Telluric occurrence of $L$. monocytogenes and other food-borne pathogens raises health issues in cultivated fields and grazing pastures as soil may be a vector of pathogens to cultivated plants and farmed animals. Hence, cattle and small ruminants are reservoirs of L. monocytogenes (Garcia et al., 1996; Nightingale et al., 2004; Fox et al., 2009). There is a body of evidence that suggests that farming practices can directly impact on the circulation and implantation of L. monocytogenes.

Ensilage of contaminated crops may result in the increase of L. monocytogenes populations in the final feed that may become the vector of cattle listeriosis (Fenlon, 1985, 1986; Wiedmann et al., 1996). 
Agricultural recycling of organic wastes without sanitation procedures is a route of transmission of L. monocytogenes to soil. Indeed, stored sewage sludges frequently contain L. monocytogenes at low levels (1-240 bacteria MPN g ${ }^{-1}$ dry matter) and their agricultural use as fertilizer without sanitation procedure may facilitate its transfer and implantation into soil (Watkins and Sleath, 1981; Alghazali and Alazawi, 1990; De Luca et al., 1998; Garrec et al., 2003). Per hectare, spreading of one to two tons of sludge would bring around $10^{6}-10^{8}$ L. monocytogenes per year (Garrec et al., 2003).

The presence of L. monocytogenes in the faeces of farm animals has been recognized (Fenlon et al., 1996; Nicholson et al., 2004; Nightingale et al., 2004). In a case-control study involving a total of 52 bovine, goat and sheep farms, the frequency of detection varied from 22 to $33 \%$ in bovine farms and from 3 to $18 \%$ in goat and sheep farms (Nightingale et al., 2004). Survival during storage of faecal wastes is limited to a few weeks but daily inputs in the storage facilities of the farmyard could maintain a constant load of viable L. monocytogenes (Vanrenterghem et al., 1991; Hutchison et al., 2005). Land spreading of these untreated wastes can contribute to the transmission of L. monocytogenes to soil. In an experiment of spreading of artificially contaminated faecal wastes on a grass pasture, 64-128 days were required until the listerial population declined to undetectable levels (Hutchison et al., 2005). In a separate experiment maximum survival period varied from 4 days to over 32 days after land application according to the type of waste (Nicholson et al., 2005). Delaying incorporation of faecal waste after land application on agricultural soils could result in a decline in the population of the pathogen (Hutchison et al., 2004). Under laboratory conditions, survival in bovine manure-amended soil varied from 21 to 43 days and depended on the dose and on the temperature of incubation (Jiang et al., 2004).

Survival up to 56 days was observed in a climatic chamber experiment designed to investigate the fate of several pathogens after spreading of anaerobic digestion residues on grass crops (Johansson et al., 2005).

Statistical integration of survey data gives interesting insights into the environmental parameters affecting the probability of occurrence of the pathogen. Ivanek et al. found a strong association between weather, soil properties and the probability to detect Listeria sp. in soil (Ivanek et al., 2009). In a recent 2 year long longitudinal study of the occurrence of food-borne pathogens in 5 fruit and vegetable farms, landscape and meteorological factors were associated to the frequency of positive samples (Strawn et al., 2013). Overall prevalence of $L$. monocytogenes was $15 \%$ while in soil, the frequency of detection was $9 \%$. This survey was exploited to develop a classification tree model. This evidenced that temperature, proximity to surface water, roads/urban development and pasture/hay grass, but also soil-related parameters (available water storage, soil organic matter) were environmental and topographic factors of importance to explain detection of L. monocytogenes (Strawn et al., 2013). Interestingly, in this survey, the frequency of detection of L. monocytogenes was highest in water samples. The quality of water used for land irrigation is of concern and transfer of pathogens through poor quality irrigation water is likely (Steele and Odumeru, 2004; Selma et al.,
2007; Ijabadeniyi et al., 2011; Oliveira et al., 2011). Proximity to dairy farms is an environmental factor that influences detection of L. monocytogenes in watersheds (Sauders et al., 2006; Lyautey et al., 2007a). Wastewater treated effluents frequently carry L. monocytogenes (Watkins and Sleath, 1981; Alghazali and Alazawi, 1990; Steele and Odumeru, 2004; Paillard et al., 2005; Odjadjare et al., 2010; Moreno et al., 2011) with loads varying from 3 to 15 CFU.ml ${ }^{-1}$ (Alghazali and Alazawi, 1990) to over $10^{3}$ CFU.ml ${ }^{-1}$ (Odjadjare et al., 2010).

\section{INTRINSIC FACTORS IN RELATION TO THE GENE CONTENT/TRANSCRIPTIONAL REGULATION}

Sequencing of the genome of $L$. monocytogenes yields insights into traits that permit persistence of the pathogen into soil. The description of the genome of L. monocytogenes EGD-e, the first sequenced strain, highlighted features relevant to the ubiquity of this species (Glaser et al., 2001). Indeed, genes encoding transport proteins represent a high proportion of the genome (11.6\% of the genome of L. monocytogenes EGD-e) $26 \%$ of them are related to the transport of carbohydrates by phosphoenolpyruvate-dependent phosphotransferase systems. It is thus equipped to have access to multiple carbon sources from varying environments. The proportion of regulatory genes is also high $(7.3 \%)$. Such an extensive repertoire of regulatory genes is expected from a versatile bacterium that thrives in many habitats. The role of some of them has been studied extensively, especially PrfA and VirR because of their importance during infection of the mammal host.

At the moment, over 20 genomes of representatives of the genus Listeria are available (4 non L. monocytogenes and 24 L. monocytogenes) (http://img.jgi.doe.gov/cgi-bin/w/main.cgi?). These are circular chromosomes ranging from 2.7 to $3.0 \mathrm{Mb}$ in length. A characteristic of these genomes is their high degree of synteny (den Bakker et al., 2012, 2013). These comparative genomic analyses identified around 4400 genes in the pangenome of L. monocytognes. Among the putative protein coding genes (between 2330 and 2465 genes) about $80 \%$ are within the core genome. This rather high proportion of core genes relative to several other species is consistent with a stable species backbone and a limited accessory genome (from 323 to 753 genes per strain) (den Bakker et al., 2013). Interestingly, genes involved in transport and metabolic processes are overrepresented in both core and accessory genomes (den Bakker et al., 2012). In silico comparison of the representation of Clusters of Orthologous Groups within the genomes of the genus Listeria, Bacillus, Lactobacillus, Staphylococcus and Streptococcus (Markowitz et al., 2012) illustrates the richness of all listerial genomes, similar to Bacillus genomes, in genes coding transport proteins and transcriptional regulators (Table 3 ). This could facilitate adaptation to various habitats, a trademark of the bacteria of the genus Bacillus and Listeria. Within the genus Listeria, the proportion of genes coding transport proteins, histidine kinases and transcriptional regulators are similar (Table 4). Noteworthy is the overrepresentation of PTS systems in both core and accessory genomes (Glaser et al., 2001; Doumith et al., 2004; Deng et al., 2010; den Bakker et al., 2013). Such a pool of carbohydrate transporters and the ability to metabolize an extended range of these carbon sources could 
Table 3 | Median number of genes from functional categories transport, histidine kinase and transcriptional regulator across selected genomes.

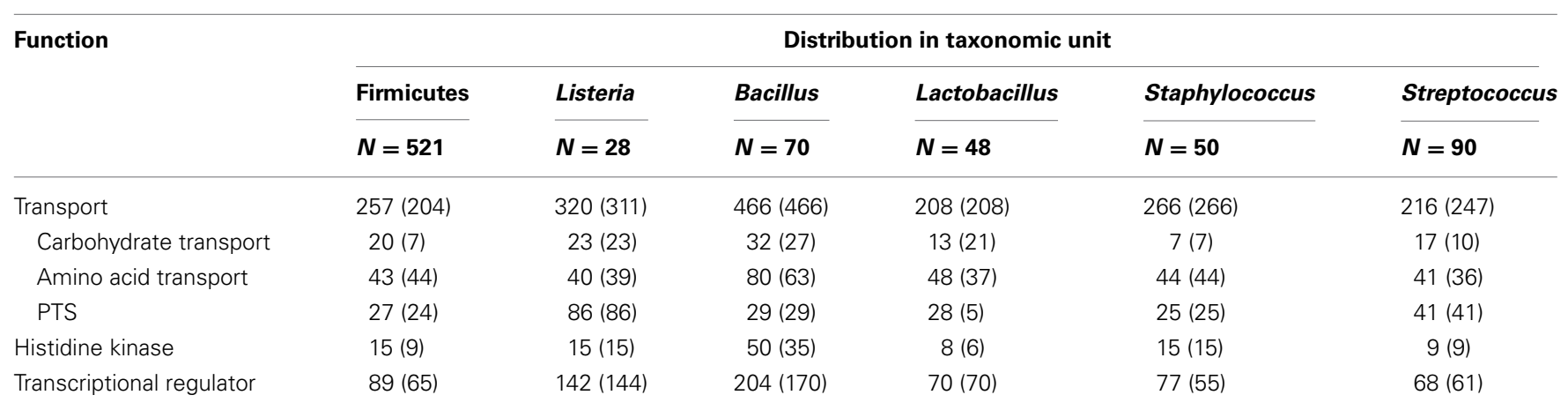

$N$ is the number of genomes considered for each taxonomic unit. The mode is presented in brackets.

Table 4 | Median number of genes from functional categories transport, histidine kinase and transcriptional regulator across the genus Listeria compared to Bacillus subtilis and Firmicutes.

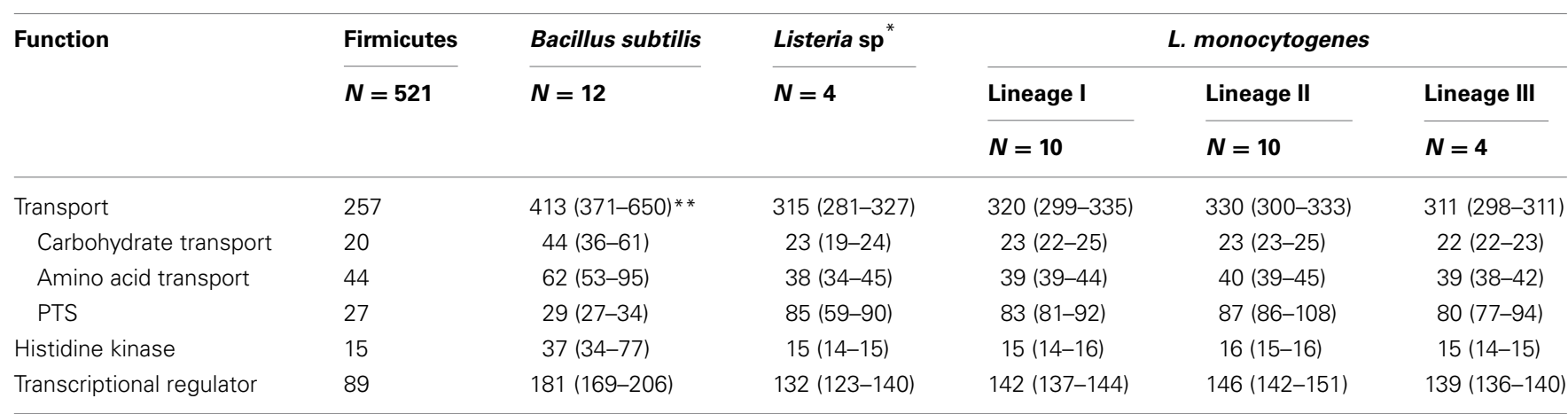

$N$ is the number of genomes considered for each taxonomic unit.

${ }^{*}$ L. welshimeri, L. innocua, L seeligeri, L. ivanovii.

** In brackets are the minimum and maximum numbers of genes found in the genome.

represent a fitness advantage under the control of selective pressure in the environment and in vivo (den Bakker et al., 2013). Under biotic conditions, the diversity of PTS systems and their possible functional redundancy could attenuate the efficacy of PTS-triggering bacteriocins (Diep et al., 2007; den Bakker et al., 2013) produced by neighboring bacteria (den Bakker et al., 2013).

Extrachromosomal DNA has been detected in many L. monocytogenes strains (Lebrun et al., 1992, 1994; McLauchlin et al., 1997; Lemaitre et al., 1998; Katharios-Lanwermeyer et al., 2012). Overrepresentation of plasmids in strains from food and saprophytic environments in comparison to those from clinical cases was reported (Lebrun et al., 1992; McLauchlin et al., 1997; Kuenne et al., 2010). A number of diverse mobile genetic elements and genes involved in heavy metal resistance (cadmium, copper, arsenite) as well as multidrug efflux and oxidative stress response are generally found on plasmids isolated from representatives of the genus Listeria (Kuenne et al., 2010). The presence of these plasmids could assist survival in food processing environments. Recently, a unique type of plasmid was found in some strains of lineage IV responsible of caprine listeriosis outbreaks (den Bakker et al., 2012). Unlike what was discussed above, this plasmid does not carry genes involved in resistance to antibiotic or heavy metals but internalin-like genes that might facilitate invasion of the caprine host. Still, the role of large plasmids in the ecology of L. monocytogenes is poorly understood although it is probably relevant to explain the fitness of isolates.

Information on the molecular mechanisms that underlie growth and persistence of L. monocytogenes in soil is scarce. Transcriptome analysis during adaptation to the soil environment showed that L. monocytogenes mobilized its repertoire of genes coding transporters (phosphoenolpyruvate-dependent phosphotransferase systems and $\mathrm{ABC}$ transporters) and enzymes involved in catabolism of specific carbohydrates ( $\beta$-glucosidases; chitinases) (Piveteau et al., 2011). It is consistent with the requirement to utilize the carbon, nitrogen and energy sources available in the soil in order to persist in this environment. Overrepresentation of genes from the SigmaB regulon was noticed (Piveteau et al., 2011). The role of SigmaB for the survival and adaptation of L. monocytogenes in soil has been demonstrated experimentally (Gorski et al., 2011). Indeed, SigmaB regulates the response and tolerance to most stresses in L. monocytogenes, including those that can be encountered in soil. A complex regulatory network underlies the ability of L. monocytogenes to thrive in diverse habitats and to respond efficiently to ever changing environmental conditions including transition from saprophytic to intracellular lifestyles (Chaturongakul et al., 2008). 
As discussed above, L. monocytogenes has the ability to avoid predation by bacteriophagous protozoans and bacteriovorous nematodes. Expression of virulence factors could be a fitness advantage during interaction with soil protozoans and other soil dwelling organisms. For example, defective mutants of act $A$ and prfA are impaired during infection of Drosophila melanogaster (Mansfield et al., 2003). Moreover, in this study, expression of act $A$ was evidenced at $25^{\circ} \mathrm{C}$ in insect cells. Similarly, listeriolysin O (LLO) is involved in the interaction with Tetrahymena pyriformis and hly deficient mutants fail to cause mortality of the ciliate (Pushkareva and Ermolaeva, 2010). As such, expression of some of the identified virulence factors could contribute to the overall fitness of L. monocytogenes in the soil ecosystem.

\section{BIODIVERSITY AND INCIDENCE IN SOIL}

One of the trademarks of the species L. monocytogenes is the wide range of environments where it is found. However, the ecological significance of the systematic definition of bacterial species is not straightforward. The concept of ecotype aims at synthesizing systematic, ecology and evolution in a new paradigm for the understanding of the ecology of microorganisms (Cohan, 2006; Cohan and Koeppel, 2008). Ecotypes are defined as "the smallest groups that (i) show a history of coexistence as separate, ecologically distinct lineages, as inferred from community ecology (or an equivalent sequence-based approach) and (ii) show a prognosis for future coexistence, as inferred from the ecological distinctness of the groups in nature" (Cohan, 2006). Whether or not ecotypes exist in the species L. monocytogenes is an open question. The phylogenetic structure of $L$. monocytogenes is complex. Isolates are grouped in four lineages and major clonal complexes are recognized (Nadon et al., 2001; Ragon et al., 2008). These major clonal complexes are distributed worldwide (Chenal-Francisque et al., 2011). Interestingly, there is evidence that distribution of clones and serotypes differ among clinical, food and environmental isolates (Wiedmann et al., 1997; Gray et al., 2004; Ward et al., 2004; Chenal-Francisque et al., 2011). However, a limitation of these studies is that the collections of isolates that were analyzed are not fully representative of the complex ecology of members of the species L. monocytogenes. Ribotyping of farm animal isolates of L. monocytogenes identified several subtypes (Gudmundsdottir et al., 2004; Nightingale et al., 2004). In a case study, Nightingale et al. showed that the incidence of one of the ribotypes was higher in soil while others were preferentially associated with faecal samples and animals listeriosis (Nightingale et al., 2004). In two recent publications, the authors compared the diversity of Listeria strains isolated from soil, water and vegetation from natural areas of the state of New York (USA) and from urban soil, water, vegetation samples and several surfaces found in cities (Sauders et al., 2006, 2012). Evidence also pointed out to higher detection of specific subtypes in specific sample sites. These results are in favor of the existence of ecotypes. However, others report on the widespread distribution of PFGE types regardless of their origin (Fugett et al., 2007).

As proposed by Cohan (Cohan, 2006), defining such ecotypes will require a clear demonstration that the ecology of isolates of the various sequence clusters is actually distinct.

\section{CONCLUSION}

Soil is a complex ecosystem central to the function of the biosphere. Agricultural use of land may raise health issues. Indeed, soil may play a pivotal role in the transfer of Human pathogens to cultivated plants and farm animals and the subsequent contamination of foodstuff. As discussed in this review, Listeria monocytogenes is a human pathogen naturally present in soil. Indeed, intrinsic factors such as an extended repertoire of transport systems, especially PTS and transcriptional regulators underlie the ability of the members of this species to persist in the soil ecosystem. However, extrinsic factors affect their ability to survive in soil. These include edaphic parameters and the biotic environment which direct the fate of $L$. monocytogenes. The natural history of members of the species L. monocytogenes is complex, circulation of the pathogen between environments is still rather poorly understood and whether or not ecotypes exist remains an open question.

Considering their ability to persist in soil, it is rather difficult to predict how anthropogenic-driven changes could modify their circulation and incidence in the biosphere. In a period of rapid global changes, when agriculture faces major adaptation challenges, understanding the ecology of Human pathogens in agroecosystems is necessary to forecast how their circulation and incidence may be affected. It is indeed a prerequisite to reassess health hazards. As a matter of fact, L. monocytogenes should be considered as a useful model organism for this purpose.

\section{REFERENCES}

Akya, A., Pointon, A., and Thomas, C. (2009). Viability of Listeria monocytogenes in co-culture with Acanthamoeba spp. FEMS Microbiol. Ecol. 70, 20-29. doi: 10.1111/j.1574-6941.2009.00736.x

Akya, A., Pointon, A., and Thomas, C. (2010). Listeria monocytogenes does not survive ingestion by Acanthamoeba polyphaga. Microbiology 156, 809-818. doi: 10.1099/mic.0.031146-0

Alghazali, M. R., and Alazawi, S. K. (1990). Listeria monocytogenes contamination of crops grown on soil treated wi0th seawage sludge cake. J. Appl. Bacteriol. 69, 642-647. doi: 10.1111/j.1365-2672.1990.tb01557.x

Anderson, G. L., Caldwell, K. N., Beuchat, L. R., and Williams, P. L. (2003). Interaction of a free-living soil nematode, Caenorhabditis elegans, with surrogates of foodborne pathogenic bacteria. J. Food Prot. 66, 1543-1549.

Anderson, G. L., Kenney, S. J., Millner, P. D., Beuchat, L. R., and Williams, P. L. (2006). Shedding of foodborne pathogens by Caenorhabditis elegans in compost-amended and unamended soil. Food Microbiol. 23, 146-153. doi: 10.1016/j.fm.2005.01.018

Barker, J., and Brown, M. R. W. (1994). Trojan horses of the microbial world - protozoa and the survival of bacterial pathogens in the environment. Microbiology 140, 1253-1259. doi: 10.1099/00221287-140-6-1253

Botzler, R. G., Cowan, A. B., and Wetzler, T. F. (1974). Survival of Listeria monocytogenes in soil and water. J. Wildl. Dis. 10, 204-212.

Caldwell, K. N., Anderson, G. L., Williams, P. L., and Beuchat, L. R. (2003). Attraction of a free-living nematode, Caenorhabditis elegans, to foodborne pathogenic bacteria and its potential as a vector of Salmonella Poona for preharvest contamination of cantaloupe. J. Food Prot. 66, 1964-1971.

Chaturongakul, S., Raengpradub, S., Wiedmann, M., and Boor, K. J. (2008). Modulation of stress and virulence in Listeria monocytogenes. Trends Microbiol. 16, 388-396. doi: 10.1016/j.tim.2008.05.006

Chenal-Francisque, V., Lopez, J., Cantinelli, T., Caro, V., Tran, C., Leclercq, A., et al. (2011). Worldwide distribution of major clones of Listeria monocytogenes. Emerg. Infect. Dis. 17, 1110-1112. doi: 10.3201/eid/1706.101778

Cohan, F. M. (2006). Towards a conceptual and operational union of bacterial systematics, ecology, and evolution. Philos. Trans. R. Soc. B Biol. Sci. 361, 1985-1996. doi: 10.1098/rstb.2006.1918 
Cohan, F. M., and Koeppel, A. F. (2008). The origins of ecological diversity in prokaryotes. Curr Biol 18, R1024-R1034. doi: 10.1016/j.cub.2008.09.014

De Luca, G., Zanetti, F., Fateh-Moghadm, P., and Stampi, S. (1998). Occurrence of Listeria monocytogenes in sewage sludge. Zentralbl. Hyg. Umweltmed. 201, 269-277.

Decaens, T. (2010). Macroecological patterns in soil communities. Glob. Ecol. Biogeogr. 19, 287-302. doi: 10.1111/j.1466-8238.2009.00517.x

den Bakker, H. C., Bowen, B. M., Rodriguez-Rivera, L. D., and Wiedmann, M. (2012). FSL J1-208, a virulent uncommon phylogenetic lineage IV Listeria monocytogenes strain with a small chromosome size and a putative virulence plasmid carrying internalin-like genes. Appl. Environ. Microbiol. 78, 1876-1889. doi: 10.1128/AEM.06969-11

den Bakker, H. C., Desjardins, C. A., Griggs, A. D., Peters, J. E., Zeng, Q. D., Young, S. K., et al. (2013). Evolutionary dynamics of the accessory genome of Listeria monocytogenes. PloS ONE 8:e67511. doi:10.1371/journal.pone.0067511

Deng, X., Phillippy, A. M., Li, Z., Salzberg, S. L., and Zhang, W. (2010). Probing the pan-genome of Listeria monocytogenes: new insights into intraspecific niche expansion and genomic diversification. BMC Genomics 11:500. doi: 10.1186/1471-2164-11-500

Diep, D. B., Skaugen, M., Salehian, Z., Holo, H., and Nes, I. F. (2007). Common mechanisms of target cell recognition and immunity for class II bacteriocins. Proc. Natl. Acad. Sci. U.S.A. 104, 2384-2389. doi: 10.1073/pnas.0608775104

Doumith, M., Cazalet, C., Simoes, N., Frangeul, L., Jacquet, C., Kunst, F., et al. (2004). New aspects regarding evolution and virulence of Listeria monocytogenes revealed by comparative genomics and DNA arrays. Infect. Immun. 72, 1072-1083. doi: 10.1128/IAI.72.2.1072-1083.2004

Dowe, M. J., Jackson, E. D., Mori, J. G., and Bell, C. R. (1997). Listeria monocytogenes survival in soil and incidence in agricultural soils. J. Food Prot. 60, 1201-1207.

Fenlon, D. R. (1985). Wild birds and silage as reservoirs of Listeria in the agricultural environment. J. Appl. Bacteriol. 59, 537-543. doi: 10.1111/j.13652672.1985.tb03357.x

Fenlon, D. R. (1986). Rapid quantitative assessment of the distribution of Listeria in silage implicated in a suspected outbreak of listeriosis in calves. Vet. Rec. 118, 240-242. doi: 10.1136/vr.118.9.240

Fenlon, D. R., Wilson, J., and Donachie, W. (1996). The incidence and level of Listeria monocytogenes contamination of food sources at primary production and initial processing. J. Appl. Bacteriol. 81, 641-650. doi: 10.1111/j.13652672.1996.tb03559.x

Forrester, S., Milillo, S. R., Hoose, W. A., Wiedmann, M., and Schwab, U. (2007). Evaluation of the pathogenicity of Listeria spp. in Caenorhabditis elegans. Foodborne Pathog. Dis. 4, 67-73. doi: 10.1089/fpd.2006.64

Fox, E., O’Mahony, T., Clancy, M., Dempsey, R., O’Brien, M., and Jordan, K. (2009). Listeria monocytogenes in the Irish dairy farm environment. J. Food Prot. 72, 1450-1456.

Fugett, E. B., Schoonmaker-Bopp, D., Dumas, N. B., Corby, J., and Wiedmann, M. (2007). Pulsed-field gel electrophoresis (PFGE) analysis of temporally matched Listeria monocytogenes isolates from human clinical cases, foods, ruminant farms, and urban and natural environments reveals source-associated as well as widely distributed PFGE types. J. Clin. Microbiol. 45, 865-873. doi: 10.1128/JCM.01285-06

Garcia, E., DePaz, M., Rodriguez, J. L., Gaya, P., Medina, M., and Nunez, M. (1996). Exogenous sources of Listeria contamination in raw ewe's milk. J. Food Prot. 59, 950-954.

Garrec, N., Picard-Bonnaud, F., and Pourcher, A. M. (2003). Occurrence of Listeria sp and L. monocytogenes in sewage sludge used for land application: effect of dewatering, liming and storage tank on survival of Listeria species. FEMS Immunol. Med. Microbiol. 35, 275-283. doi: 10.1016/S0928-8244(02)00443-1

Gibbs, D. S., Anderson, G. L., Beuchat, L. R., Carta, L. K., and Williams, P. L. (2005). Potential role of Diploscapter sp strain LKC25, a bacterivorous nematode from soil, as a vector of food-borne pathogenic bacteria to preharvest fruits and vegetables. Appl. Environ. Microbiol. 71, 2433-2437. doi: 10.1128/AEM.71.5.2433-2437.2005

Glaser, P., Frangeul, L., Buchrieser, C., Rusniok, C., Amend, A., Baquero, F., et al. (2001). Comparative genomics of Listeria species. Science 294, 849-852. doi: $10.1126 /$ science. 1063447

Gorski, L., Duhe, J. M., and Flaherty, D. (2011). The Sigma B operon is a determinant of fitness for a Listeria monocytogenes serotype $4 \mathrm{~b}$ strain in soil. Foodborne Pathog. Dis. 8, 699-704. doi: 10.1089/fpd.2010.0752
Gourabathini, P., Brandl, M. T., Redding, K. S., Gunderson, J. H., and Berk, S. G. (2008). Interactions between food-borne pathogens and protozoa isolated from lettuce and spinach. Appl. Environ. Microbiol. 74, 2518-2525. doi: 10.1128/AEM.02709-07

Gray, M. J., Zadoks, R. N., Fortes, E. D., Dogan, B., Cai, S., Chen, Y., et al. (2004). Listeria monocytogenes isolates from foods and humans form distinct but overlapping populations. Appl. Environ. Microbiol. 70, 5833-5841. doi: 10.1128/AEM.70.10.5833-5841.2004

Griffiths, B. S., and Philippot, L. (2013). Insights into the resistance and resilience of the soil microbial community. FEMS Microbiol. Rev. 37, 112-129. doi: 10.1111/j.1574-6976.2012.00343.x

Gudmundsdottir, K. B., Aalbaek, B., Sigurdarson, S., and Gunnarsson, E. (2004). The diversity of Listeria monocytogenes strains from 10 Icelandic sheep farms. J. Appl. Microbiol. 96, 913-921. doi: 10.1111/j.1365-2672.2004.02183.x

Guha, S., Klees, M., Wang, X. X., Li, J., Dong, Y. Q., and Cao, M. (2013). Influence of planktonic and sessile Listeria monocytogenes on Caenorhabditis elegans. Arch. Microbiol. 195, 19-26. doi: 10.1007/s00203-012-0841-y

Harf, C. (1994). Free living ameba-interactions with environmental pathogenic bacteria. Endocyt. Cell Res 10, 167-183.

Hutchison, M. L., Walters, L. D., Moore, A., Crookes, K. M., and Avery, S. M. (2004). Effect of length of time before incorporation on survival of pathogenic bacteria present in livestock wastes applied to agricultural soil. Appl. Environ. Microbiol.70, 5111-5118. doi: 10.1128/AEM.70.9.5111-5118.2004

Hutchison, M. L., Walters, L. D., Moore, T., Thomas, D. J. I., and Avery, S. M. (2005). Fate of pathogens present in livestock wastes spread onto fescue plots. Appl. Environ. Microbiol. 71, 691-696. doi: 10.1128/AEM.71.2.691-696.2005

Ijabadeniyi, O. A., Debusho, L. K., Vanderlinde, M., and Buys, E. M. (2011). Irrigation water as a potential preharvest source of bacterial contamination of vegetables. J. Food Saf. 31, 452-461. doi: 10.1111/j.1745-4565.2011.00321.x

Ivanek, R., Grohn, Y. T., Wells, M. T., Lembo, A. J., Sauders, B. D., and Wiedmann, M. (2009). Modeling of spatially referenced environmental and meteorological factors influencing the probability of Listeria species isolation from natural environments. Appl. Environ. Microbiol. 75, 5893-5909. doi: 10.1128/AEM.02757-08

Jiang, X. P., Islam, M., Morgan, J., and Doyle, M. P. (2004). Fate of Listeria monocytogenes in bovine manure-amended soil. J. Food Protec. 67, 1676-1681.

Johansson, M., Emmoth, E., Salomonsson, A. C., and Albihn, A. (2005). Potential risks when spreading anaerobic digestion residues on grass silage cropssurvival of bacteria, moulds and viruses. Grass Forage Sci. 60, 175-185. doi: 10.1111/j.1365-2494.2005.00466.x

Katharios-Lanwermeyer, S., Rakic-Martinez, M., Elhanafi, D., Ratani, S., Tiedje, J. M., and Kathariou, S. (2012). Coselection of cadmium and benzalkonium chloride resistance in conjugative transfers from nonpathogenic Listeria spp. to other Listeriae. Appl. Environ. Microbiol. 78, 7549-7556. doi: 10.1128/AEM.02245-12

Kogel-Knabner, I., Guggenberger, G., Kleber, M., Kandeler, E., Kalbitz, K., Scheu, S., et al. (2008). Organo-mineral associations in temperate soils: integrating biology, mineralogy, and organic matter chemistry. J. Plant Nutr. Soil Sci.-Z. Pflanzenernahr. Bodenkd. 171, 61-82. doi: 10.1002/jpln.2007 00048

Kuenne, C., Voget, S., Pischimarov, J., Oehm, S., Goesmann, A., Daniel, R., et al. (2010). Comparative analysis of plasmids in the genus Listeria. PloS ONE 5:e12511. doi: 10.1371/journal.pone.0012511

Kuzina, L. V., Peloquin, J. J., Vacek, D. C., and Miler, T. A. (2001). Isolation and identification of bacteria associated with adult laboratory Mexican fruit flies, Anastrepha ludens (Diptera: Tephritidae). Curr. Microbiol. 42, 290-294. doi: 10.1007/s002840110219

Lapanje, A., Zrimec, A., Drobne, D., and Rupnik, M. (2010). Long-term Hg pollution-induced structural shifts of bacterial community in the terrestrial isopod (Porcellio scaber) gut. Environ. Pollut. 158, 3186-3193. doi: 10.1016/j.envpol.2010.07.001

Lebrun, M., Audurier, A., and Cossart, P. (1994). Plasmid-borne cadmium resistance genes in Listeria monocytogenes are similar to cadA and cadC of Staphylococcus aureus and are induced by cadmium. J. Bacteriol. 176, 3040-3048.

Lebrun, M., Loulergue, J., Chaslusdancla, E., and Audurier, A. (1992). Plasmids in Listeria monocytogenes in relation to cadmium resistance. Appl. Environ. Microbiol. 58, 3183-3186.

Lemaitre, J. P., Echchannaoui, H., Michaut, G., Divies, C., and Rousset, A. (1998). Plasmid-mediated resistance to antimicrobial agents among listeriae. J. Food Protec. 61, 1459-1464. 
Locatelli, A., Depret, G., Jolivet, C., Henry, S., Dequiedt, S., Piveteau, P., et al. (2013a). Nation-wide study of the occurrence of Listeria monocytogenes in French soils using culture-based and molecular detection methods. J. Microbiol. Meth. 93, 242-250. doi: 10.1016/j.mimet.2013.03.017

Locatelli, A., Spor, A., Jolivet, C., Piveteau, P., and Hartmann, A. (2013b). Biotic and abiotic soil properties influence survival of Listeria monocytogenes in soil. PloS ONE 8:e75969. doi:10.1371/journal.pone.0075969

Ly, T. M. C., and Muller, H. E. (1990). Interactions of Listeria monocytogenes, Listeria seeligeri and Listeria innocua with protozoans. J. Gen. Appl. Microbiol. 36, 143-150. doi: 10.2323/jgam.36.143

Lyautey, E., Lapen, D. R., Wilkes, G., McCleary, K., Pagotto, F., Tyler, K., et al. (2007a). Distribution and characteristics of Listeria monocytogenes isolates from surface waters of the South Nation River watershed, Ontario, Canada. Appl. Environ. Microbiol. 73, 5401-5410. doi: 10.1128/AEM.00354-07

Lyautey, E., Hartmann, A., Pagotto, F., Tyler, K., Lapen, D. R., Wilkes, G., et al. (2007b). Characteristics and frequency of detection of fecal Listeria monocytogenes shed by livestock, wildlife, and humans. Can. J. Microbiol. 53, 1158-1167. doi: 10.1139/W07-084

MacGowan, A. P., Bowker, K., McLauchlin, J., Bennett, P. M., and Reeves, D. S. (1994). The occurrence and seasonal changes in the isolation of Listeria spp in shop bought food stuffs, human feces, sewage and soil from urban sources. Int. J. Food Microbiol. 21, 325-334. doi: 10.1016/0168-1605(94)90062-0

Mansfield, B. E., Dionne, M. S., Schneider, D. S., and Freitag, N. E. (2003). Exploration of host-pathogen interactions using Listeria monocytogenes and Drosophila melanogaster. Cell. Microbiol. 5, 901-911. doi: 10.1046/j.14625822.2003.00329.x

Markowitz, V. M., Chen, I.-M., Palaniappan, K., Chu, K., Szeto, E., Grechkin, Y., et al. (2012). IMG: the integrated microbial genomes database and comparative analysis system. Nucleic Acids Res. 40, D115-D122. doi: 10.1093/nar/gkr1044

McLauchlin, J., Hampton, M. D., Shah, S., Threlfall, E. J., Wieneke, A. A., and Curtis, G. D. W. (1997). Subtyping of Listeria monocytogenes on the basis of plasmid profiles and arsenic and cadmium susceptibility. J. Appl. Microbiol. 83, 381-388. doi: 10.1046/j.1365-2672.1997.00238.x

McLaughlin, H. P., Casey, P. G., Cotter, J., Gahan, C. G. M., and Hill, C. (2011). Factors affecting survival of Listeria monocytogenes and Listeria innocua in soil samples. Arch. Microbiol. 193, 775-785. doi: 10.1007/s00203-011-0716-7

Moreno, Y., Ballesteros, L., Garcia-Hernandez, J., Santiago, P., Gonzalez, A., and Ferrus, M. A. (2011). Specific detection of viable Listeria monocytogenes in Spanish wastewater treatment plants by Fluorescent In Situ Hybridization and PCR. Water Res. 45, 4634-4640. doi: 10.1016/j.watres.2011.06.015

Nadon, C. A., Woodward, D. L., Young, C., Rodgers, F. G., and Wiedmann, M. (2001). Correlations between molecular subtyping and serotyping of Listeria monocytogenes. J. Clin. Microbiol. 39, 2704-2707. doi: 10.1128/JCM.39.7.27042707.2001

Nannipieri, P., Ascher, J., Ceccherini, M. T., Landi, L., Pietramellara, G., and Renella, G. (2003). Microbial diversity and soil functions. Eur. J. Soil Sci. 54, 655-670. doi: 10.1046/j.1351-0754.2003.0556.x

Nicholson, F. A., Chambers, B. J., Moore, A., Nicholson, R. J., and Hickman, G. (2004). Assessing and managing the risks of pathogen transfer from livestock manures into the food chain. Water Environ. J. 18, 155-160. doi: 10.1111/j.17476593.2004.tb00518.x

Nicholson, F. A., Groves, S. J., and Chambers, B. J. (2005). Pathogen survival during livestock manure storage and following land application. Bioresour. Technol. 96, 135-143. doi: 10.1016/j.biortech.2004.02.030

Nightingale, K. K., Schukken, Y. H., Nightingale, C. R., Fortes, E. D., Ho, A. J., Her, Z., et al. (2004). Ecology and transmission of Listeria monocytogenes infecting ruminants and in the farm environment. Appl. Environ. Microbiol. 70, 4458-4467. doi: 10.1128/AEM.70.8.4458-4467.2004

Odjadjare, E. E., Obi, L. C., and Okoh, A. I. (2010). Municipal wastewater effluents as a source of listerial pathogens in the aquatic milieu of the eastern Cape province of South Africa: a concern of public health importance. Int. J. Environ. Res. Publ. Health 7, 2376-2394. doi: 10.3390/ijerph7052376

Oliveira, M., Usall, J., Vinas, I., Solsona, C., and Abadias, M. (2011). Transfer of Listeria innocua from contaminated compost and irrigation water to lettuce leaves. Food Microbiol. 28, 590-596. doi: 10.1016/j.fm.2010.11.004

Paillard, D., Dubois, W., Thiebaut, R., Nathier, F., Hoogland, E., Caumette, P., et al. (2005). Occurrence of Listeria spp. in effluents of French urban wastewater treatment plants. Appl. Environ. Microbiol. 71, 7562-7566. doi: 10.1128/AEM.71.11.7562-7566.2005
Picardbonnaud, F., Cottin, J., and Carbonnelle, B. (1989). Persistence of Listeria monocytogenes in 3 sorts of soil. Act. Microbiol. Hung. 36, 263-267.

Piveteau, P., Depret, G., Pivato, B., Garmyn, D., and Hartmann, A. (2011). Changes in gene expression during adaptation of Listeria monocytogenes to the soil environment. PLOS ONE 6:e24881. doi: 10.1371/journal.pone. 0024881

Pushkareva, V. I., and Ermolaeva, S. A. (2010). Listeria monocytogenes virulence factor Listeriolysin $\mathrm{O}$ favors bacterial growth in co-culture with the ciliate Tetrahymena pyriformis, causes protozoan encystment and promotes bacterial survival inside cysts. BMC Microbiol. 10:26. doi: 10.1186/1471-2180-10-26

Ragon, M., Wirth, T., Hollandt, F., Lavenir, R., Lecuit, M., Le Monnier, A., et al. (2008). A new perspective on Listeria monocytogenes evolution. PloS Pathogens 4:e1000146. doi: 10.1371/journal.ppat.1000146

Sauders, B. D., Durak, M. Z., Fortes, E., Windham, K., Schukken, Y., Lembo, A. J., et al. (2006). Molecular characterization of Listeria monocytogenes from natural and urban environments. J. Food Protec. 69, 93-105.

Sauders, B. D., Overdevest, J., Fortes, E., Windham, K., Schukken, Y., Lembo, A., et al. (2012). Diversity of Listeria species in urban and natural environments. Appl. Environ. Microbiol. 78, 4420-4433. doi: 10.1128/AEM.00282-12

Selma, M. V., Allende, A., Lopez-Galvez, F., Elizaquivel, P., Aznar, R., and Gil, M. I. (2007). Potential microbial risk factors related to soil amendments and irrigation water of potato crops. J. Appl. Microbiol. 103, 2542-2549. doi: 10.1111/j.1365-2672.2007.03504.x

Sezen, X., Demir, I., and Demirbag, Z. (2004). Study of the bacterial flora as a biological control agent of Agelastica alni L (Coleoptera: Chrysomelidae). Biologia $59,327-331$.

Sidorenko, M. L., Buzoleva, L. S., and Kostenkov, N. M. (2006). The effect of soil properties on the preservation and reproduction of Listeria and Yersinia. Eurasian Soil Sci. 39, 211-217. doi: 10.1134/S1064229306020128

Smith, L. W. (2001). The incidence of potentially pathogenic bacteria in liquor from selected wormfarms. Biol. Fert. Soils 34, 215-217. doi: 10.1007/s003740 100374

Steele, M., and Odumeru, J. (2004). Irrigation water as source of foodborne pathogens on fruit and vegetables. J. Food Protec. 67, 2839-2849.

Strawn, L. K., Fortes, E. D., Bihn, E. A., Nightingale, K. K., Grohn, Y. T., Worobo, R. W., et al. (2013). Landscape and meteorological factors affecting prevalence of three food-borne pathogens in fruit and vegetable farms. Appl. Environ. Microbiol. 79, 588-600. doi: 10.1128/AEM.02491-12

Thomsen, L. E., Slutz, S. S., Tan, M. W., and Ingmer, H. (2006). Caenorhabditis elegans is a model host for Listeria monocytogenes. Appl. Environ. Microbiol. 72, 1700-1701. doi: 10.1128/AEM.72.2.1700-1701.2006

Vanrenterghem, B., Huysman, F., Rygole, R., and Verstraete, W. (1991). Detection and prevalence of Listeria monocytogenes in the agricultural system. J. Appl. Bacteriol. 71, 211-217. doi: 10.1111/j.1365-2672.1991.tb04450.x

Vivant, A. L., Garmyn, D., Maron, P. A., Nowak, V., and Piveteau, P. (2013). Microbial diversity and structure are drivers of the biological barrier effect against Listeria monocytogenes in soil. PloS ONE 8:e76991. doi: 10.1371/journal.pone.0076991

Ward, T. J., Gorski, L., Borucki, M. K., Mandrell, R. E., Hutchins, J., and Pupedis, K. (2004). Intraspecific phylogeny and lineage group identification based on the prfA virulence gene cluster of Listeria monocytogenes. J. Bacteriol. 186, 4994-5002. doi: 10.1128/JB.186.15.4994-5002.2004

Wardle, D. A. (2006). The influence of biotic interactions on soil biodiversity. Ecol. Lett. 9, 870-886. doi: 10.1111/j.1461-0248.2006.00931.x

Watkins, J., and Sleath, K. P. (1981). Isolation and enumeration of Listeria monocytogenes from Sewage, Sewage Sludge and River Water. J. Appl. Bacteriol. 50, 1-9. doi: 10.1111/j.1365-2672.1981.tb00865.x

Weis, J., and Seeliger, H. P. (1975). Incidence of Listeria monocytogenes in nature. Appl. Microbiol. 30, 29-32.

Welshimer, H. J. (1960). Survival of Listeria monocytogenes in soil. J. Bacteriol. 80, 316-320.

Welshimer, H. J., and Donker-Voet, J. (1971). Listeria monocytogenes in nature. Appl. Microbiol. 21, 516-519.

Wiedmann, M., Bruce, J. L., Knorr, R., Bodis, M., Cole, E. M., McDowel, C. I., et al. (1996). Ribotype diversity of Listeria monocytogenes strains associated with outbreaks of listeriosis in ruminants. J. Clin. Microbiol. 34, 1086-1090.

Wiedmann, M., Bruce, J. L., Keating, C., Johnson, A. E., McDonough, P. L., and Batt, C. A. (1997). Ribotypes and virulence gene polymorphisms suggest three 
distinct Listeria monocytogenes lineages with differences in pathogenic potential. Infect. Immun. 65, 2707-2716.

Yoshida, T., Sugimoto, T., Sato, M., and Hirai, K. (2000). Incidence of Listeria monocytogenes in Wild Animals in Japan. J. Vet. Med. Sci. 62, 673-675. doi: $10.1292 /$ jvms. 62.673

Zhou, X. H., Elmose, J., and Call, D. R. (2007). Interactions between the environmental pathogen Listeria monocytogenes and a free-living protozoan (Acanthamoeba castellanii). Environ. Microbiol. 9, 913-922. doi: 10.1111/j.14622920.2006.01213.x

Conflict of Interest Statement: The authors declare that the research was conducted in the absence of any commercial or financial relationships that could be construed as a potential conflict of interest.
Received: 16 October 2013; paper pending published: 03 November 2013; accepted: 08 November 2013; published online: 28 November 2013.

Citation: Vivant A-L, Garmyn D and Piveteau P (2013) Listeria monocytogenes, a down-to-earth pathogen. Front. Cell. Infect. Microbiol. 3:87. doi: 10.3389/fcimb. 2013.00087

This article was submitted to the journal Frontiers in Cellular and Infection Microbiology.

Copyright (0) 2013 Vivant, Garmyn and Piveteau. This is an open-access article distributed under the terms of the Creative Commons Attribution License (CC BY). The use, distribution or reproduction in other forums is permitted, provided the original author(s) or licensor are credited and that the original publication in this journal is cited, in accordance with accepted academic practice. No use, distribution or reproduction is permitted which does not comply with these terms. 